\section{蛇平開拓地における新規水田造成とその意義}

\section{長谷川 典 夫}

磐梯山北麓，小野川湖南側の泥流地域に位置 する蛇平は，1944 年周辺集落より 22 户が入植 した典型的な高冷開拓地である。近年新規水田 の造成と既成耕地の放稁がみられ，生産構造に 変化を生じたので，その実情を記し，水田造成 の意義に注目しておきたい。

蛇平では，当初小野川・五色沼入口間の道路 添いが主に開拓され，雑穀作を主とする畑作が 行なわれ，その後わずかの水田が付加されてい つた。しかし標高 760～800 メートルの開拓地 では低温・日照不足など気候的にも，また泥流 地域特有の巨碟が多く極浅土層であるなど士壤 の点でも，作物の成育条件が劣恶であり，耕地 化が困難なう光生産力も低く，兼業は必須の要 件であった。

1958 年の国の 開拓事業実施要領の 改訂に対 応して，当地区の営農型も転換してゆく。すな わら, 開拓組合は五色沼入口に近い所有地を観 光用地として売却し，乙の資金約 1200 万円を もって 貯水地を新設し，小野川湖東南岸に 約 $10 h a$ の水田を機械開墾により造成し，1960年 より水稲栽培を開始した。1 戸当り面積は $50 a$ 程度に過ざず，生産力も $10 a$ 当り 2 〜 2.4 石と 低いがこれによって自給が汪保可能となっ た。1 戸当り $2 h a$ 以下の畑地には，なたね・ たばこ・ばれいしよ・雑穀などが栽培され，換 金作物の意義は少なくないが，生産力は低い。 既成耕地は，1963～64 年に家屋の 移転集合の 場に提供された注加は，新規水田造成後放髙さ れたままのものが多い。一般に農作業住農繁期 をのぞき女子労働に依存し，男子は国有林労務 や出稼に従事して家計費の半ばを得ているが，

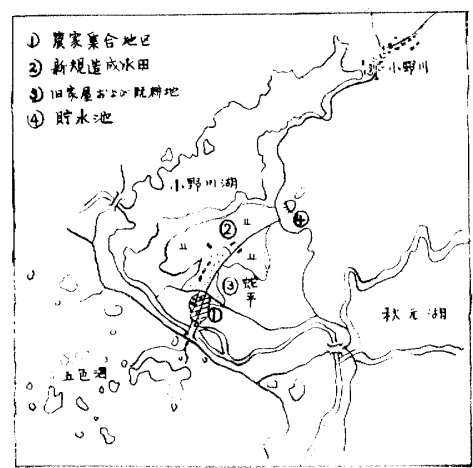

水田造成前後でこの事情は変っていない。

以上のように，時の農業政策を背景とし，機 械開篡の導入によって新規水田を造成した蛇平 では，一方では既成不良耕地を放率し，一度導 入した酸農も牧草の生育不良や牛乳の出荷条 件の不良のため廃止し, 現在の営農の基幹は水 田経営にあるが，一方では兼業の果す役割もま た極めて大きい。従って蛇平で虫, 品種の改 良・稲作技術の進歩・機械開墾力式の導入など を前提としながらも，経済的基盤が弱体な開拓 農村であるからこそ自給度の高い米作指向の欲 求か強くあらわれて, 水田造成が行なわれたと みるべきであろう。その点では下北半島の野平 開拓地（長谷川1965）の如き低生産力の僻地開 拓地と軌を一にするものであって，昭和開懇

(福井 1966) や磐梯山南麓の東部開拓地にみら れる，自給畑作 $\rightarrow$ 畑作十酷農 $\rightarrow$ 水田造成による 水田酷農という営農基盤の強化に伴なう発展型 とは意義が異なる。

(1967.2.22 受理)

福井英夫（1966）：昭和畑作開拓地における水田造

成 東北地理 1886

長谷川典夫（1965）：下北半島の戦後開拓地 人類科学 $17 \quad 16 \sim 32$

\title{
New Gonstruction of Rice Fields in the Hebidaira Settlement
}

\section{Norio HASEGAWA}

The Hebidaira settlement at the northern slope of Mt. Bandai, is under unfavourable conditions for farming such as cold climate and poor soils originated from volcanic mud-flows. The farmers carrying on ordinary field farming are so poor that they are in need of side jobs. In 1960, the farmers newly reclaimed about $10 \mathrm{ha}$ of waste land into rice fields and also constructed a reservoir as a new irrigation source. On the other hand, they abandoned their old upland-fields and rice-fields which were less favourable for farming. However, farm economy in the newly reclaimed rice-fields is not always prosperous. It is a different type from the cases of Showa settlement and Tobu settlement. 